See Article page 85 .

\section{Commentary: Adapting for our patients: Reducing intraoperative adverse events as new technologies emerge}

\author{
Weiang Yan, MD, ${ }^{\mathrm{a}, \mathrm{b}}$ and \\ Michael H. Yamashita, MDCM, MPH, FRCSC ${ }^{\mathrm{a}, \mathrm{b}}$
}

Cardiac surgery uses increasingly complex and high-risk interventions to care for patients with severe cardiovascular diseases. Although morbidity and mortality have improved significantly in the modern era of cardiac surgery, errors in the operating room remain a major cause of preventable adverse events and avoidable death. ${ }^{1,2}$ Therefore, it is prudent to examine individual cases of surgical missteps to learn from them and avoid repeating these mistakes in the future.

In this issue of the Journal, Fukunaga and colleagues ${ }^{3}$ describe a case of inappropriate aortic cannula placement for central venoarterial extracorporeal membrane oxygenation and the complications that ensued. The arterial cannula used in this case was placed too deeply into the distal ascending aorta, with its tip residing in the descending thoracic aorta. The patient sustained a localized iatrogenic aortic dissection (iAD) near the cannula tip, cannularelated thrombosis, acute renal injury, and stroke, which may or may not have been related to the extracorporeal membrane oxygenation cannula. Fortunately, the patient successfully recovered from these complications and was discharged to home with no significant long-term sequelae.

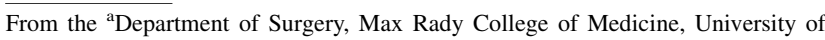
Manitoba and ${ }^{\mathrm{b}}$ Cardiac Sciences Program, St. Boniface Hospital, Winnipeg, Manitoba, Canada

Disclosures: Dr Yan is supported by a Canadian Institutes of Health Research Fellowship (MEF-171305). Dr Yamashita reported no conflicts of interest.

The Journal policy requires editors and reviewers to disclose conflicts of interest and to decline handling or reviewing manuscripts for which they may have a conflict of interest. The editors and reviewers of this article have no conflicts of interest.

Received for publication Nov 29, 2020; revisions received Nov 29, 2020; accepted for publication Dec 15, 2020; available ahead of print Dec 25, 2020.

Address for reprints: Michael H. Yamashita, MDCM, MPH, FRCSC, Y3519-409 Tache Ave, Winnipeg, Manitoba, Canada R2H 2A6 (E-mail: myamashita@sbgh. mb.ca).

JTCVS Techniques 2021;6:88-9

2666-2507

Copyright (c) 2020 The Authors. Published by Elsevier Inc. on behalf of The American Association for Thoracic Surgery. This is an open access article under the CC BY-NCND license (http://creativecommons.org/licenses/by-nc-nd/4.0/).

https://doi.org/10.1016/j.xjtc.2020.12.012

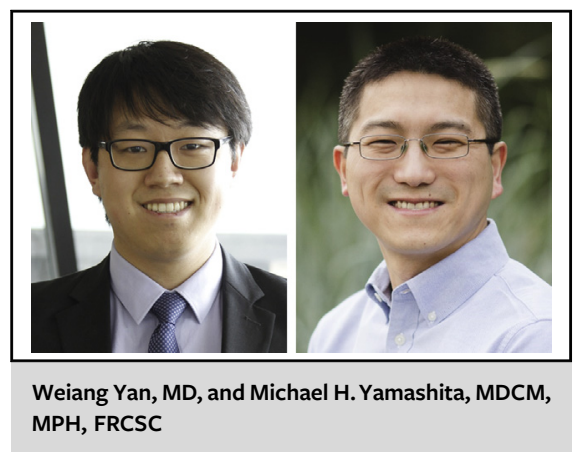

CENTRAL MESSAGE

As new technologies emerge, cardiac surgeons must ensure that they are well trained in all aspects of the field and are familiar with all equipment used in their practice.

However, these and future downstream complications likely could have been prevented had the correct technique been used for cannula placement.

This case provides 2 important learning points. First, cardiac surgeons must be well trained in all aspects of the field and be familiar with all the equipment used in their practice. Despite ample efforts to combat contributing system factors, individual human factors remain an important cause of intraoperative errors and patient injuries. ${ }^{4}$ In particular, a surgeon's lack of technical competence or knowledge is cited as a contributing factor in almost one-half of all surgical malpractice claims. ${ }^{5,6}$ These were predominantly cases in which surgeons were practicing within their specialty but lacking knowledge or skill with specific tasks at hand. ${ }^{6}$ With the adoption of novel therapies into the standard of care of cardiac surgery, surgeons must adapt and ensure they are properly trained to deliver these new standards. This is especially true regarding mechanical circulatory support, a subspecialty of cardiac surgery where new techniques and devices are continuously being introduced to our practices. A study among vascular surgeons in England identified equipment unfamiliarity to be significantly predictive of intraoperative failure. ${ }^{7} \mathrm{~A}$ formal training curriculum and high-fidelity simulation models can be used to gain knowledge and experience with these new techniques and technologies. ${ }^{8}$

Second, cardiac surgeons must remain vigilant for $\mathrm{iAD}$ when using venoarterial extracorporeal membrane 
oxygenation. In this population, the reported incidence is as high as $1.4 \%{ }^{9}$ Early recognition of iAD is key to reducing mortality; it should always be suspected when there are sudden changes to systemic arterial pressure (and pulse waveform), decreases in flow rate, increases in extracorporeal membrane oxygenation arterial line pressure, and/or evidence of decreased organ perfusion. ${ }^{10}$ As shown in this report, transesophageal echocardiography is a safe and effective modality for diagnosing and guiding management of iAD in critically ill patients.

Thus, as the field of cardiac surgery evolves, it remains incumbent on us to keep abreast of novel techniques and technologies. Our patients depend on it.

\section{References}

1. Martinez EA, Thompson DA, Errett NA, Kim GR, Bauer L, Lubomski LH, et al. High stakes and high risk: a focused qualitative review of hazards during cardiac surgery. Anaesthes Analges. 2011;112:1061-74.

2. Wahr JA, Prager RL, Abernathy JH III, Martinez EA, Salas E, Seifert PC, et al. Patient safety in the cardiac operating room: human factors and teamwork: a scientific statement from the American Heart Association. Circulation. 2013;128: 1139-69.
3. Fukunaga N, Badiwala MV, Yau TM, Rao V, Cusimano RJ. Descending aortic thrombosis and acute type B dissection during central extracorporeal membrane oxygenation: a word of caution. J Thorac Cardiovasc Surg Tech. 2021;6:85-7.

4. Fabri PJ, Zayas-Castro JL. Human error, not communication and systems, underlies surgical complications. Surgery. 2008;144:557-65.

5. Rogers SO, Gawande AA, Kwaan M, Puopolo AL, Yoon C, Brennan TA, et al Analysis of surgical errors in closed malpractice claims at 4 liability insurers. Surgery. 2006;140:25-33.

6. Regenbogen SE, Greenberg CC, Studdert DM, Lipsitz SR, Zinner MJ, Gawande AA. Patterns of technical error among surgical malpractice claims: an analysis of strategies to prevent injury to surgical patients. Ann Surg. 2007; 246:705-11.

7. Lear R, Riga C, Godfrey AD, Falaschetti E, Cheshire NH, Van Herzeele I, et al. Multicentre observational study of surgical system failures in aortic procedures and their effect on patient outcomes. Br J Surg. 2016;103:1467-75.

8. Lorusso R, Whitman G, Milojevic M, Raffa G, McMullan DM, Boeken U, et al. 2020 EACTS/ELSO/STS/AATS expert consensus on post-cardiotomy extracorporeal life support in adult patients. Ann Thorac Surg. 2020;111: P327-69.

9. Mariscalco G, Salsano A, Fiore A, Dalén M, Ruggieri VG, Saeed D, et al. Peripheral versus central extracorporeal membrane oxygenation for postcardiotomy shock: multicenter registry, systematic review, and meta-analysis. J Thorac Cardiovasc Surg. 2020;160:1207-16.

10. Ram H, Dwarakanath S, Green AE, Steyn J, Hessel EA. Iatrogenic aortic dissection associated with cardiac surgery: a narrative review. J Cardiothorac Vasc Anesth. 2020; https://doi.org/10.1053/j.jvca.2020.07.084 [Epub ahead of print]. 